\title{
Ibalizumab: First Global Approval
}

\author{
Anthony Markham ${ }^{1}$
}

Published online: 19 April 2018

(C) Springer Nature 2018, corrected publication May/2018

\begin{abstract}
TaiMed Biologics is developing ibalizumab (Trogarzo $^{\mathrm{TM}}$, ibalizumab-uiyk) —a humanised IgG4 monoclonal antibody-as a treatment for HIV-1 infection. Ibalizumab blocks HIV entry into CD4 cells while preserving normal immunological function and is the first CD4-directed post-attachment HIV-1 inhibitor and the first humanised monoclonal antibody for the treatment of HIV/ AIDS. This article summarizes the milestones in the development of ibalizumab leading to this first approval in HIV-1 treatment.
\end{abstract}

\section{Introduction}

Ibalizumab (Trogarzo ${ }^{\mathrm{TM}}$, ibalizumab-uiyk) is a humanised IgG4 monoclonal antibody being developed by TaiMed Biologics for the treatment of HIV-1 infection. Ibalizumab blocks HIV entry into CD4 cells without impairing normal immunological function. The drug is the first CD4-directed post-attachment HIV-1 inhibitor and the first humanised monoclonal antibody for the treatment of HIV/AIDS. Ibalizumab is approved in the USA for use as part of a combination antiretroviral regimen in heavily treatment-

The original version of this article was revised due to a retrospective Open Access request.

This profile has been extracted and modified from the AdisInsight database. AdisInsight tracks drug development worldwide through the entire development process, from discovery, through pre-clinical and clinical studies to market launch and beyond.

Anthony Markham

dru@adis.com

1 Springer, Private Bag 65901, Mairangi Bay, 0754 Auckland, New Zealand experienced patients with multidrug resistant (MDR) HIV1 infection failing their current antiretroviral regimen [1]. The recommended dose of ibalizumab is a single intravenous $2000 \mathrm{mg}$ loading dose followed by an intravenous maintenance dose of $800 \mathrm{mg}$ once every 2 weeks [2].

\subsection{Company Agreements}

Ibalizumab was originally developed by Biogen. In the late 1990s Biogen licensed the exclusive worldwide rights to ibalizumab to Tanox Inc. In January 2007 Tanox entered into an agreement with Genentech which subsequently led to Genentech acquiring all shares in Tanox for a total cash price of $\approx$ \$US919 million [3] and-shortly thereafterGenentech licensing ibalizumab to TaiMed Biologics (TaiMed). In August 2012 TaiMed contracted WuXi PharmaTech to manufacture ibalizumab in support of phase II and III clinical trials [4]. In March 2016 TaiMed entered into a 12-year collaboration agreement with Theratechnologies for the latter to market and distribute ibalizumab in the US and Canada. Theratechnologies made a \$US1 million cash payment to TaiMed upon signing the agreement and will pay a further \$US1 million as shares at the commercial launch. TaiMed may also receive a further conditional \$US8.5 million payment at commercial launch, as well as various milestone payments [5]. In March 2017 this agreement was amended to grant Theratechnologies commercialisation rights for ibalizumab in the EU, Israel, Norway, Russia and Switzerland for a 12-year term following regulatory approval on a country-by-country basis, subject to further upfront and milestone payments. 




Key milestones in the development of ibalizumab

\subsection{Patent Information}

The patents for ibalizumab expired in Europe, Canada, and Australia in 2011, and expired in the US (US-05871732) in 2016, subject to extensions; with orphan drug status in the US, ibalizumab has an extended period of exclusivity through to 2025 [6]. The patent application in Japan is still pending. Ibalizumab is described and claimed in WO09209305 .

\section{Scientific Summary}

\subsection{Pharmacodynamics}

Ibalizumab binds to domain 2 of the CD4 receptor on the surface opposite both the major histocompatibility complex-class II binding site and the gp120 binding site [7, 8].

The baseline in vitro susceptibility of HIV to ibalizumab was determined in isolates from 38 of 40 heavily pretreated patients with multidrug resistant HIV-1 entering in the phase III TMB-301 clinical trial. Mean ibalizumab maximum percent inhibition (MPI) of viral replication was $91 \%$ overall, and $90-100 \%$ against 27 isolates, 80 to $90 \%$ against 6 and $<80 \%$ against 5 . The overall mean fold change in the concentration of drug required to inhibit 50\% of the MPI ( $\mathrm{IC}_{\text {halfmax }}$ fold change) [occurring at the midpoint of the dose response curve] was 1.2. Ibalizumab had mean MPI values of $81,98,89$, and $91 \%$ and mean $\mathrm{IC}_{\text {halfmax }}$ fold changes of $1.3,0.9,1.1$ and 1.0 against isolates with wild-type susceptibility to nucleoside reverse transcriptase inhibitors (NRTIs), non-nucleoside reverse transcriptase inhibitors (NNRTIs), protease inhibitors (PIs) and integrase inhibitors (INIs), respectively, compared to respective mean MPI values of $94,91,91$, and $92 \%$ and mean $\mathrm{IC}_{\text {halfmax }}$ fold changes of 1.2, 1.2, 1.3, and 1.1 against isolates that were resistant to all NRTIs, NNRTIs, PIs, or INIs. The drug had MPI values of $84-99 \%$ and $\mathrm{IC}_{\text {halfmax }}$ fold change values of 0.7 to 1.4 against 5 of 6 isolates with reduced susceptibility to enfuvirtide at screening; one isolate with reduced susceptibility to enfuvirtide at screening also had reduced susceptibility to ibalizumab

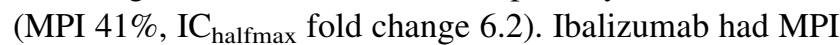
values of 94 and $100 \%$ against two isolates exhibiting CCR5-dependent replication with reduced susceptibility to maraviroc (MPI 58 and 0\%) [9].

The in vitro activity of ibalizumab has also been assessed against a panel of 116 Tier-2 Env-pseudotyped viruses selected to represent envelope diversity by geography, clade, tropism, and stage of infection, including 30 transmitted/founder viruses. Ibalizumab achieved 50 and $80 \%$ inhibition of infection in 92 and $65 \%$ of these HIV strains, respectively. The median half maximal inhibitory concentration of ibalizumab $(0.03 \mathrm{mg} / \mathrm{ml})$ was an order of magnitude lower than those of the HIV-neutralizing monoclonal antibodies PG9 $(0.11 \mathrm{mg} / \mathrm{ml})$, and VRC01 $(0.22 \mathrm{mg} / \mathrm{ml})$, and two orders of magnitude lower than those of 4E10, 2F5, $2 \mathrm{G} 12$ and b12. Analyses of gp160 sequence polymorphism revealed the predominant determinant of resistance to ibalizumab was the absence of a potential asparagine (N)-linked glycosylation site (PNGS) at the variable region (V5) N-terminus. Other independent correlates of resistance were PNGS at position 386 and the side chain length of residue 375 . Ibalizumab exhibited complementary resistance to VRC01 and SCD4 which was partly mediated by the V5 PNGS [7]. Loss of V5 PNGS was also associated with resistance to ibalizumab in HIV-1 isolates from patients $(\mathrm{n}=14)$ participating in a phase $\mathrm{Ib}$ study [10].

\subsection{Pharmacokinetics}

The pharmacokinetic properties of intravenous ibalizumab have been investigated in an open-label, randomized phase Ib study in patients with HIV-1 infection [11]. Patients were randomised to intravenous ibalizumab $10 \mathrm{mg} / \mathrm{kg}$ on day 1 then once weekly for 9 weeks $(\mathrm{n}=9)$ or $10 \mathrm{mg} / \mathrm{kg}$ on day one then $6 \mathrm{mg} / \mathrm{kg}$ at weeks $1,3,5,7$ or $9(\mathrm{n}=10)$. A further three (non-randomised) patients received ibalizumab $25 \mathrm{mg} / \mathrm{kg}$ on day 1 and weeks $2,4,6$, and $8 . \mathrm{C}_{\max }$ 
Features and properties of ibalizumab

\begin{tabular}{|c|c|}
\hline Alternative names & Trogarzo $^{\mathrm{TM}}$, ibalizumab-uiyk, TMB-355, TNX-355, TMB-355, Hu5A8, monoclonal antibody 5A8 \\
\hline Class & CD4-directed post-attachment HIV-1 inhibitor, Antiretrovirals, Humanized monoclonal antibodies \\
\hline Mechanism of Action & Binds to domain 2 of the CD4 receptor \\
\hline Route of Administration & Intravenous \\
\hline Pharmacodynamics & Blocks HIV-1 infection in CD4 T-cells \\
\hline Pharmacokinetics & $\begin{array}{l}\mathrm{C}_{\max } 402 \mu \mathrm{g} / \mathrm{ml}, \mathrm{AUC}_{\text {all }} 3604 \mu \mathrm{g} \cdot \mathrm{day} / \mathrm{ml}, \mathrm{t}_{1} / 2.3 \text { days, volume of distribution } 44 \mathrm{ml} / \mathrm{kg} \text {, steady } \\
\text { state clearance } 5.7 \mathrm{ml} / \mathrm{day} / \mathrm{kg}\end{array}$ \\
\hline \multicolumn{2}{|l|}{ Adverse events } \\
\hline Most frequent & Diarrhoea, dizziness, nausea, rash \\
\hline \multicolumn{2}{|l|}{ ATC codes } \\
\hline WHO ATC code & J05A-X (Other antivirals) \\
\hline EphMRA ATC code & J5C4 (HIV antivirals, entry inhibitors) \\
\hline Chemical name & $\begin{array}{l}\text { Immunoglobulin G4, anti-(human CD4 (antigen)) (human-mouse monoclonal 5A8 } \gamma 4 \text {-chain), } \\
\text { disulphide with human-mouse monoclonal 5A8 } \kappa \text {-chain, dimer }\end{array}$ \\
\hline
\end{tabular}

and $\mathrm{AUC}_{\text {all }}$ were $402 \mu \mathrm{g} / \mathrm{ml}$ and $3604 \mu \mathrm{g} \cdot \mathrm{day} / \mathrm{ml}$, respectively, in the $10 \mathrm{mg} / \mathrm{kg}$ group and $564 \mu \mathrm{g} / \mathrm{ml}$ and $4941 \mu \mathrm{g} \cdot$ day $/ \mathrm{ml}$, respectively, in the $25 \mathrm{mg} / \mathrm{kg}$ group. The elimination half-life was 3.3 and 3.1 days in the 10 and $25 \mathrm{mg} / \mathrm{kg}$ groups, respectively, volume of distribution at steady state 44 and $50 \mathrm{ml} / \mathrm{kg}$, respectively, and steady state clearance 5.7 and $8.8 \mathrm{ml} / \mathrm{day} / \mathrm{kg}$, respectively. Trough ibalizumab serum concentrations were 48,31 and $96 \mu \mathrm{g} / \mathrm{ml}$ in the $10 \mathrm{mg} / \mathrm{kg}, 10 / 6 \mathrm{mg} / \mathrm{kg}$ and $25 \mathrm{mg} / \mathrm{kg}$ groups respectively prior to week 1 infusion, and 138, 0.2 and $96 \mu \mathrm{g} / \mathrm{ml}$, respectively, prior to the final dose. Considerable $(110 \%)$ variability in serum drug concentrations was evident later in the dosing period among the three patients who received ibalizumab $25 \mathrm{mg} / \mathrm{kg}$ [11].

When administered as recommended (an initial 2,000 mg loading dose then $800 \mathrm{mg}$ once every 2 weeks), ibalizumab concentrations reached steady-state levels after the first $800 \mathrm{mg}$ maintenance dose with mean concentrations $>30 \mu \mathrm{g} / \mathrm{ml}$ throughout the dosing interval [2].

\subsection{Therapeutic Trials}

\subsubsection{Multidrug Resistant HIV-1 Infection}

2.3.1.1 Phase III Ibalizumab plus an optimised background antiretroviral regimen maintained virologic efficacy in treatment-experienced patients $(n=40)$ with multidrug resistant HIV-1 infection in an open-label phase III study (TMB-301, NCT02475629). Median viral load and CD4+ $\mathrm{T}$ cell count were $4.6 \log _{10}(18 \%$ baseline viral load $\geq$ 100,000 copies $/ \mathrm{ml}$ ) and 73 cells/ $\mu \mathrm{l}$, respectively, at baseline. Resistance to $\geq 3$ and 4 antiretroviral drug classes was present in 53 and $35 \%$ of patients, respectively, and $13 \%$ of patients had HIV-1 resistant to all approved antiretroviral agents. Patients received intravenous ibalizumab at an initial dose of $2000 \mathrm{mg}$ then $800 \mathrm{mg}$ once every two weeks, plus an optimised background regimen, for 24 weeks. Seven days following the initial $2000 \mathrm{mg}$ ibalizumab-loading dose, 33 patients $(83 \%)$ experienced a $\geq$ $0.5 \log 10$ decrease in HIV RNA, whereas 1 patient $(3 \%)$ experienced $\mathrm{a} \geq 0.5 \log 10$ decrease in HIV RNA during Control period $(\mathrm{p}<0.0001)$ [12]. Mean viral load was reduced by $1.6 \log _{10}$ from baseline to week 24 (intention to treat-missing equals failure analysis) in patients receiving ibalizumab. Reductions in viral load of $\geq 1 \log _{10}$ and $\geq 2$ $\log _{10}$ occurred in 55 and $48 \%$ of patients, respectively, and 43 and $50 \%$ of patients had a viral load $<50$ and $<200$ HIV RNA copies/ml, respectively [13].

Of patients who completed study TMB-301 ( $\mathrm{n}=31)$, only patients from US and Puerto Rico were eligible to enter study TMB-311 (NCT02707861), where they continued to receive ibalizumab $800 \mathrm{mg}$ once every two weeks for up to 48 weeks. This study enrolled 27 patients of whom 59 and $33 \%$ had HIV-1 infection resistant to $\geq 3$ and $\geq 4$ antiretroviral classes, respectively. $7 \%$ of patents had HIV-1 resistant to all approved antiretroviral classes. 24 patients received treatment until week 48 . The median reduction in viral load from baseline in these 27 patients was $2.5 \log _{10}$ at both week 24 and $48.16(59 \%)$ and $17(63 \%)$ patients had a viral load of $<$ 50 and $<200$ HIV RNA copies/ml, respectively. All patients with a viral load of $<50$ copies/ml at week $24(n=15)$ maintained viral suppression to week 48 [14].

2.3.1.2 Phase II Treatment with ibalizumab plus an optimised background antiretroviral regimen resulted in significant reductions in viral load in a 24-week randomised, double-blind, phase IIb study (TMB-202, NCT00784147). 113 patients with HIV-1 infection and 
Key clinical trials of intravenous ibalizumab (TaiMed Biologics)

\begin{tabular}{|c|c|c|c|c|c|c|}
\hline $\operatorname{Drug}(\mathrm{s})$ & Indication & Phase & Patients & Status & Location (s) & Identifier \\
\hline Ibalizumab & HIV-1 infection & Ia & 30 & Completed & USA & N/A \\
\hline $\begin{array}{l}\text { Ibalizumab plus optimised } \\
\text { background regimen }\end{array}$ & $\begin{array}{l}\text { Treatment naïve or previously } \\
\text { treated HIV-1 infection }\end{array}$ & $\mathrm{Ib}$ & 22 & Completed & USA & N/A \\
\hline $\begin{array}{l}\text { Ibalizumab plus optimised } \\
\text { background regimen, placebo }\end{array}$ & Previously treated HIV-1 infection & IIa & 82 & Completed & $\begin{array}{l}\text { USA, Puerto } \\
\text { Rico, Canada }\end{array}$ & $\begin{array}{l}\text { NCT00089700, } \\
\text { TNX-355.03 }\end{array}$ \\
\hline $\begin{array}{l}\text { Ibalizumab plus optimised } \\
\text { background regimen }\end{array}$ & Previously treated HIV-1 infection & IIb & 113 & Completed & $\begin{array}{l}\text { USA, Puerto } \\
\text { Rico }\end{array}$ & $\begin{array}{l}\text { NCT00784147, } \\
\text { TMB-202 }\end{array}$ \\
\hline $\begin{array}{l}\text { Ibalizumab plus optimised } \\
\text { background regimen }\end{array}$ & $\begin{array}{l}\text { Previously treated HIV- } 1 \text { infection, } \\
\text { PI-IND extension of IIb }\end{array}$ & II & 56 & Completed & USA & NCT01056393 \\
\hline $\begin{array}{l}\text { Ibalizumab plus optimised } \\
\text { background regimen }\end{array}$ & Multidrug resistant HIV-1 infection & III & 40 & Completed & $\begin{array}{l}\text { USA, Puerto } \\
\text { Rico, Taiwan }\end{array}$ & $\begin{array}{l}\text { NCT02475629, } \\
\text { TMB-301 }\end{array}$ \\
\hline $\begin{array}{l}\text { Ibalizumab plus optimised } \\
\text { background regimen }\end{array}$ & Multidrug resistant HIV-1 infection & III & 27 & Ongoing & $\begin{array}{l}\text { USA, Puerto } \\
\text { Rico }\end{array}$ & $\begin{array}{l}\text { NCT02707861, } \\
\text { TMB-311 }\end{array}$ \\
\hline
\end{tabular}

documented resistance to at least 1 NRTI, 1 NNRTI and 1 PI were randomised to treatment with an optimized background antiretroviral regimen plus intravenous ibalizumab $800 \mathrm{mg}$ once every 2 weeks $(\mathrm{n}=59)$ or $2000 \mathrm{mg}$ once every 4 weeks $(n=54)$. The primary endpoint was the proportion of patients with viral load $<50$ copies $/ \mathrm{ml}$ at week 24.44 and $28 \%$ of patients, respectively, had a viral load of $<50$ copies/ml and 53 and $43 \%$, respectively, had a viral load of $<200$ copies/ml at week 24 . The median reduction in viral load from baseline to week 24 was 1.6 and $1.5 \log _{10}$ in ibalizumab 800 and $2000 \mathrm{mg}$ recipients, respectively [15].

\subsection{Adverse Events}

The most common adverse reactions (all grades) reported in $\geq 5 \%$ of the 40 patients who participated in trial TMB301 were diarrhoea $(8 \%)$, dizziness $(8 \%)$, nausea $(5 \%)$, and rash $(5 \%) .90 \%$ of adverse reactions reported were mild or moderate in severity. Drug-related severe adverse reactions were observed in two patients; one developed a severe rash and the other developed immune reconstitution inflammatory syndrome manifesting as an exacerbation of progressive multifocal leukoencephalopathy [2].

Laboratory abnormalities $\geq$ grade 3 reported in trial TMB-301 included bilirubin $\geq 2.6$ times the upper limit of normal (ULN) [5\%], direct bilirubin > ULN (3\%), creatinine $>1.8$ times ULN or 1.5 times baseline $(10 \%)$, blood glucose $>250 \mathrm{mg} / \mathrm{dl}(3 \%)$, lipase $>3.0$ times ULN (5\%), uric acid $>12 \mathrm{mg} / \mathrm{dl}(3 \%)$, haemoglobin $<8.5 \mathrm{~g} / \mathrm{dl}(3 \%)$, platelets $<50000 / \mathrm{mm}^{3}(3 \%)$, leukocytes $<1.5 \times 10^{9}$ cells/l $(5 \%)$ and neutrophils $<0.6 \times 10^{9}$ cells/1 (5\%) [2].

As with all therapeutic proteins, there is potential for ibalizumab to cause immunogenicity. Among patients enrolled in trials TMB-301 and TMB-202, one developed low titre anti-ibalizumab antibodies. No adverse reactions or reduced efficacy was attributed to the positive sample observed in this patient [2].

\subsection{Ongoing Clinical Trials}

The Expanded Access Program for ibalizumab in resistant HIV-1 infection is ongoing and enrolling patients (TMB311; NCT02707861).

\section{Current Status}

Ibalizumab received its first global approval on 6 March 2018 in the US for the treatment of heavily treatmentexperienced patients with multidrug resistant HIV-1 infection in combination with other antiretroviral medicines.

\section{Compliance with Ethical Standards}

Funding The preparation of this review was not supported by any external funding.

Conflict of interest During the peer review process the manufacturer of the agent under review was offered an opportunity to comment on the article. Changes resulting from any comments received were made by the author on the basis of scientific completeness and accuracy. A. Markham, a contracted employee of Adis/Springer, is responsible for the article content and declares no relevant conflicts of interest.

Open Access This article is distributed under the terms of the Creative Commons Attribution-NonCommercial 4.0 International License (http://creativecommons.org/licenses/by-nc/4.0/), which permits any noncommercial use, duplication, adaptation, distribution and reproduction in any medium or format, as long as you give appropriate credit to the original author(s) and the source, provide a link to the Creative Commons license and indicate if changes were made. 


\section{References}

1. US FDA. FDA approves new HIV treatment for patients who have limited treatment options [media release]. 6 Mar 2018. https://www.fda.gov/newsevents/newsroom/pressannouncements/ ucm599657.htm.

2. US FDA. TROGARZO ${ }^{\mathrm{TM}}$ (ibalizumab-uiyk): US prescribing Information. 2018. www.accessdata.fda.gov/drugsatfda_docs/ label/2018/761065lbl.pdf. Accessed 21 Mar 2018.

3. Genentech Inc. Genentech announces expiration of Hart-ScottRodino waiting period and completes acquisition of Tanox [media release]. 3 Aug 2007. http://www.gene.com.

4. TaiMed Biologics. WuXi PharmaTech to manufacture ibalizumab for TaiMed Biologics [media release]. 28 Aug 2012. http://www.taimedbiologics.com.

5. Theratechnologies, TaiMed Biologics. Theratechnologies and TaiMed Biologics sign exclusive marketing and distribution agreement for ibalizumab [media release]. 18 Mar 2016. http:// www.theratech.com.

6. US FDA. Orphan Drug Designations and Approvals. https:// www.accessdata.fda.gov/scripts/opdlisting/oopd/detailedIndex. cfm?cfgridkey=321910. Accessed 10 Apr 2018.

7. Pace CS, Fordyce MW, Franco D, et al. Anti-CD4 monoclonal antibody ibalizumab exhibits breadth and potency against HIV-1, with natural resistance mediated by the loss of a V5 glycan in envelope. J Acquir Immune Defic Syndr. 2013;62(1):1-9.

8. Freeman MM, Seaman MS, Rits-Volloch S, et al. Crystal structure of HIV-1 primary receptor CD4 in complex with a potent antiviral antibody. Structure. 2010;18(12):1632-41.

9. Weinheimer S, Cohen Z, Marsolais C, et al. Ibalizumab susceptibility in patient HIV isolates resistant to antiretrovirals [abstract no. 561]. In: 25th Conference on Retroviruses and Opportunistic Infections. 2018.

10. Toma J, Weinheimer SP, Stawiski E, et al. Loss of asparaginelinked glycosylation sites in variable region 5 of human immunodeficiency virus type 1 envelope is associated with resistance to CD4 antibody ibalizumab. J Virol. 2011;85(8):3872-80.

11. Jacobson JM, Kuritzkes DR, Godofsky E, et al. Safety, pharmacokinetics, and antiretroviral activity of multiple doses of ibalizumab (formerly TNX-355), an anti-CD4 monoclonal antibody, in human immunodeficiency virus type 1-infected adults. Antimicrob Agents Chemother. 2009;53(2):450-7.

12. Lalezari J, Fessel WJ, Schrader S, et al. Primary efficacy endpoint and safety results of ibalizumab in a phase 3 study of heavily treatment-experienced patients with multidrug-resistant human immunodeficiency virus-1 infection [abstract no. LB-6 plus oral presentation]. Open Forum. Infectious Diseases. 2016;3(Suppl. 1):S1.

13. Lewis S, Fessel J, Emu B, et al. Long-acting ibalizumab in patients with multi-drug resistant HIV-1: a 24-week study [abstract no. 438 plus poster 449LB]. In: 24th conference on retroviruses and opportunistic infections. 2017.

14. Emu B, Fessel WJ, Schrader S, et al. Forty-eight-week safety and efficacy on-treatment analysis of ibalizumab in patients with multi-drug resistant HIV-1 [abstract no. 1686 plus oral presentation]. Open Forum. Infect Dis. 2017;4(Suppl. 1):S38-9.

15. Khanlou H, Gathe JJ, Schrader S, et al. Safety, efficacy, and pharmacokinetics of ibalizumab in treatment-experienced HIV-1 infected patients: a phase $2 \mathrm{~b}$ study [abstract no. $\mathrm{H} 2-794 \mathrm{~b}$ plus oral presentation]. In: 51st Interscience Conference on Antimicrobial Agents and Chemotherapy. 2011. 